\title{
Performances Study of Natural and Conventional Building Insulation Materials
}

\author{
Gokhan Yildiz $^{\mathrm{a}}$, Benjamin Durakovićb,*, Ali Abd Almisreb ${ }^{\mathrm{b}}$ \\ a Department of Mechanical Engineering, Duzce University, Düzce Üniversitesi Konuralp Yerleşkesi, Duzce, 81620, Turkey \\ ${ }^{b}$ Department of Industrial Engineering, International University of Sarajevo, Hrasnička cesta 15, Sarajevo, 71000, Bosnia \\ Corresponding author: *bdurakovic@ius.edu.ba
}

\begin{abstract}
This research aims to investigate the performances of thermal insulation materials using a comparative analysis. Particularly, the performances of natural insulation materials are compared with performances of non-renewables (petrochemical and inorganic), such as thermal conductivity, thermal diffusivity, global warming potential, and cost. In the past twenty years, the interest for the research on building energy demand reduction has been increased rapidly. Buildings were identified as a significant contributor to global energy consumption and global warming through the heating and air-conditioning systems. The literature observed that building energy demand takes up to $40 \%$ of the global energy consumption. Trends in addressing this issue are based on better thermal insulation of building envelope or using more energy-efficient materials. To carry out this research, the data were collected based on published research and comparatively analyzed. It was found that natural insulation materials have a significantly lower impact on global warming, longer useful lifetime, competitive thermal properties, better fire resistance, and favorable cost. Future trends and developments in reducing building energy demand would rely on sustainability. Sustainability is based on renewable natural resources, including renewable insulation materials, but if combined with significant participation of PCMs for latent heat energy storage, it will provide much better results. To get sustainable technologies applicable in full scale in the future, the overall problem has to be investigated, including user training and addressing the future workforce's challenges.
\end{abstract}

Keywords - Renewable insulation materials; performance analysis; energy storage.

\section{INTRODUCTION}

Strong economic growth and increasing population in the past thirty years have led to a rapid increase in world energy consumption. Today, energy conversion and electricity generation are mainly based on fossil fuels and nuclear energy that produce waste products in an irreversible cycle. Fossil and nuclear fuel reserves are limited and cause many damages to the environment. According to current consumption rates, coal reserves will be consumed in approximately 130 years, natural gas in about 60 years, and oil in 40 years [2].

Only $17 \%$ of energy generation comes from renewable sources; the rest comes from non-renewable. The generated energy is dominantly consumed by industry and buildings [3]. Since buildings are a significant contributor in energy consumption, mainly through heating and cooling, it is essential to have reduced building energy demand. A way to achieve this goal is to improve thermal behavior through better insulation of building envelope [4], [5], and using passive buildings with energy storage [6], [7], [8], [9].
A significant share of the energy consumption for heating and cooling are building. The use of heat insulation materials to reduce heat loss/gain through building envelope has been studied frequently [10]. Publications related to insulation materials have been increasing rapidly over the past two decades. The studies are based on numerical and experimental data, such as the experiment's design [11]. The number of publications per year from 1960 until 2018 is shown in Figure 1.

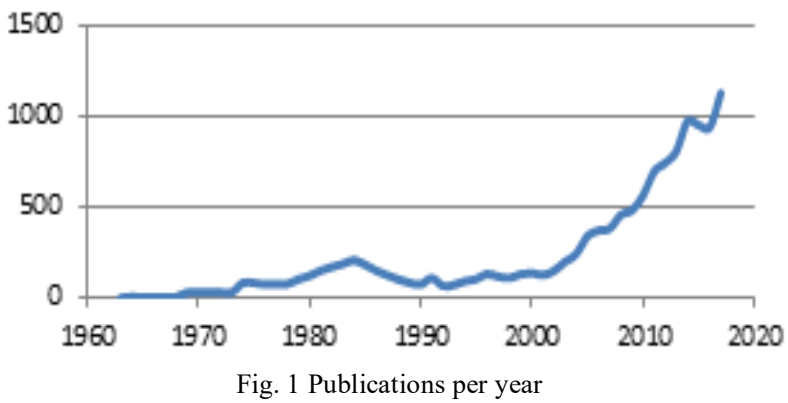


Recent studies in building envelope insulation have shifted towards alternative ways and reduced building energy demand [12]. Awareness of energy conservation has risen in many fields over the globe. This caused a search for new material development and application to achieve this goal [13]. Based on Scopus data, most publications come from European Union (EU), which is about $43 \%$ of the total published work. Accordingly, EU is the most concerned about building insulation and energy savings. The US and China are together providing about $25 \%$ of published work in Scopus. It can be seen from the literature this problem is frequently studied by researchers, and it confirms that insulation material selection is an essential step in building design; it has a significant impact on global warming and frequently attracts researcher's attentions.

The risk of global warming is increasing day by day. For this reason, it is challenging to find new insulation materials that have good thermal properties and, at the same time that they are environmentally friendly [14]. Natural renewable insulation material can promise building applications to achieve more sustainable engineering [15] and a healthier environment. Compared to the traditional non-renewable materials, renewable materials have significantly better performances, such as less impact on global warming, longer useful lifetime [16], and lower thermal diffusivity [17]. Renewable insulation materials have comparable thermal properties and may be advantageous in thermal and moisture buffering [18], heat insulation performances, fire resistance, and cost [17]. Insulation materials such as wool, wheat and so on are natural and they are considered sustainable and they can be recycled [19], while traditional insulation materials play a major role in environmental pollution [20], [21].

\section{A. Classification of Insulation Materials}

There are many classifications in different sources for insulation materials in different sources. In this study, insulation materials were separated into three groups. These groups are inorganic, organic, and new technology materials. Inorganic materials contain such as rock wool, vermiculite, glass wool, calcium silicate, foam glass, and perlite. Organic materials were collected in two groups as organic and renewable. Petrochemical materials include extruded polystyrene, expanded polystyrene, polyurethane, phenolformaldehyde, polyisocyanurate, and urea-formaldehyde. Renewable materials contain hemp wool, cellulose, coconut, flax wool, sheep wool, recycled cotton, expanded cork, and wood wool. New technology materials contain such as gas insulation, vacuum insulation, dynamic insulation, nano insulation, and nanocon.

Thermal insulation materials have fire classification in terms of building safety. This classification is of great importance because it significantly impacts the application and selection of insulation materials. Classification is specified in the European standard EN-13501-1. In this standard, there are seven classes: A1, A2, B, C, D, E, and F. Here, A1 means non-flammable, and $\mathrm{E}$ means the most flammable insulating material [22]. Classification is shown in Table I.

TABLE I

Fire ClassificAtion ACCORding TO EUROPEAN STANDARD EN-13501-1 [23]

\begin{tabular}{cc}
\hline Euro-class & Classification \\
Contribution to fire/aspired safety level & $\begin{array}{c}\text { according to } \\
\text { DIN } 4102\end{array}$ \\
\hline
\end{tabular}

F Products for which no reaction to fire performances are determined or cannot be classified in one of the classes A1, A2, B, C, D, E.

E Products capable of resisting, for a short period, a small flame attack without sustainable flame spread.

Products satisfying criteria for class E and capable of resisting, for a longer period, a small flame

D attack without substantial flame spread. In addition, they are also capable of undergoing thermal attack by a single burning item with sufficiently delayed and limited heat release.

C As class D but satisfying more stringent requirements. Additionally, under the thermal attack by a single burning item they have limited lateral spread of flame.

B As class $\mathrm{C}$ but satisfying more stringent requirements.

Satisfying the same criteria as class B. In addition, under conditions of a fully developed fire these products will not significantly contribute to the fire load and fire growth.

Class A1 products will not contribute to any stage of the fire, including the fully developed fire. For that reason, they are assumed to be capable of satisfying all requirements of all lower classes automatically.

Conventional insulation materials have been used for a long time. Properties of insulation materials are shown in Table II. Conventional insulation materials were used in the market commonly. However, in recent years, researchers have focused on renewable insulation materials due to global warming because inorganic and petrochemical insulation materials cause environmental pollution. Therefore, renewable insulation materials gain importance. 
TABLE II

PROPERTIES OF INSULATION MATERIALS

\begin{tabular}{|c|c|c|c|c|c|c|}
\hline Material & $\begin{array}{l}\text { Density } \\
\left(\mathrm{kg} / \mathrm{m}^{3}\right)\end{array}$ & $\begin{array}{c}\text { Thermal } \\
\text { conductivity } \\
(\mathrm{W} / \mathbf{m K})\end{array}$ & $\begin{array}{c}\text { Specific heat } \\
(\mathrm{J} / \mathrm{kgK})\end{array}$ & $\begin{array}{l}\text { Fire resistance } \\
\text { (Euroclass) }\end{array}$ & $\begin{array}{c}\text { Water vapor } \\
\text { diffusion } \\
\text { resistance }\end{array}$ & References \\
\hline \multicolumn{7}{|c|}{ Inorganic } \\
\hline Glass wool & $15-75$ & $0.030-0.040$ & 1000 & $\mathrm{~A} 1-\mathrm{A} 2$ & $1-1.1$ & {$[21]$} \\
\hline Rock wool & $40-200$ & $0.030-0.040$ & 1000 & A1 & $1-2$ & [21] \\
\hline Calcium Silicate & $200-240$ & $0.059-0.065$ & 1000 & A1 & $6-20$ & {$[22]$} \\
\hline Foam glass & $100-200$ & $0.038-0.055$ & 1000 & A1 & 400 & [22] \\
\hline Perlite & $80-150$ & $0.040-0.060$ & 800 & A1 & $2-3$ & {$[22][19]$} \\
\hline Vermiculite & $30-150$ & $0.040-0.064$ & 900 & A1 & $2-3$ & {$[22][19]$} \\
\hline \multicolumn{7}{|c|}{ Petrochemical } \\
\hline Expanded polystyrene & $10-35$ & $0.032-0.045$ & 1250 & E-F & $20-70$ & {$[22][19]$} \\
\hline Extruded polystyrene & $32-40$ & $0.025-0.040$ & 1700 & $\mathrm{E}$ & $80-300$ & {$[23][19]$} \\
\hline Phenol formaldehyde & $40-160$ & $0.020-0.021$ & 1190 & B-D & $30-50$ & {$[18][24]$} \\
\hline Polyurethane & $15-45$ & $0.022-0.035$ & 1400 & $\mathrm{D}-\mathrm{F}$ & $30-170$ & {$[22][19]$} \\
\hline Polyisocyanurate & $30-45$ & $0.020-0.035$ & 1450 & $\mathrm{D}-\mathrm{F}$ & $55-150$ & {$[22][19]$} \\
\hline Urea formaldehyde & 15 & 0.045 & 1200 & $\mathrm{D}-\mathrm{F}$ & $1.5-2.4$ & {$[22][24]$} \\
\hline \multicolumn{7}{|c|}{ Renewable } \\
\hline Cellulose (paper wool) & $30-80$ & $0.038-0.040$ & 1300 & $\mathrm{E}$ & $1.7-3$ & {$[22][19]$} \\
\hline Coconut & $70-120$ & $0.040-0.045$ & 1670 & $\mathrm{E}$ & $1-10$ & {$[22][19]$} \\
\hline Flax (flax wool) & $20-100$ & $0.035-0.040$ & 1600 & $\mathrm{C}$ & $1-2$ & {$[22][19]$} \\
\hline Hemp (hemp wool) & $30-82$ & $0.038-0.040$ & 1700 & $\mathrm{E}$ & $1-2$ & {$[22][19]$} \\
\hline Recycled cotton & $25-45$ & $0.039-0.044$ & 1600 & $\mathrm{E}$ & $1-2$ & {$[22][19]$} \\
\hline Sheep wool & $10-25$ & $0.035-0.040$ & 1700 & $\mathrm{E}$ & $1-3$ & {$[22][19]$} \\
\hline Wood wool & $55-140$ & $0.038-0.058$ & 2100 & $\mathrm{E}$ & 5 & {$[22]$} \\
\hline Expanded cork & $100-170$ & $0.037-0.043$ & 1700 & $\mathrm{E}$ & $5-30$ & [22] \\
\hline
\end{tabular}

Another essential property of insulation material is shown in Table III. In this table is shown which insulation material is good as environmentally friendly. Renewable insulation materials are better than inorganic and petrochemical materials as global warming potential.

TABLE III

ANOTHER IMPORTANT PROPERTIES OF INSULATION MATERIALS

\begin{tabular}{|c|c|c|c|c|c|}
\hline Material & $\begin{array}{c}\text { Thermal } \\
\text { diffusivity }\left[\mathrm{m}^{2} / \mathrm{s}\right]\end{array}$ & Cost $\left[€ / \mathbf{m}^{3}\right]$ & $\begin{array}{c}\text { Energy } \\
\text { consumption } \\
\text { (MJeq per f.u.) }\end{array}$ & $\begin{array}{c}\text { Global warming } \\
\text { potential (kg } \\
\mathrm{CO}_{2} \text { eq per f.u.) }\end{array}$ & References \\
\hline \multicolumn{6}{|c|}{ Inorganic } \\
\hline Glass wool & $(2 \mathrm{E}-06)-(5.33 \mathrm{E}-07)$ & $77.5-147$ & 229.02 & 9.89 & {$[22][19][25]$} \\
\hline Rock wool & (7.5E-07)-(2E-07) & $102.08-179.5$ & 63.34 & 3.62 & {$[22][19][25]$} \\
\hline Calcium Silicate & $(3 \mathrm{E}-07)-(2.71 \mathrm{E}-07)$ & $95-285$ & 55.8 & 4.25 & {$[22][26]$} \\
\hline Foam glass & $(3.8 \mathrm{E}-07)-(2.8 \mathrm{E}-07)$ & $357.38-445.5$ & 208 & 19.439 & {$[22][19][25]$} \\
\hline Perlite & $(6.3 \mathrm{E}-07)-(5 \mathrm{E}-07)$ & 207.89-207.89 & 67.31 & 3.99 & {$[22][19][27]$} \\
\hline Vermiculite & $(1.5 \mathrm{E}-06)-(4.7 \mathrm{E}-07)$ & 152.6 & 53.37 & 3.36 & {$[22][19]$} \\
\hline \multicolumn{6}{|c|}{ Petrochemical } \\
\hline Expanded polystyrene & $(1.7 \mathrm{E}-06)-(1 \mathrm{E}-06)$ & $61.42-186.56$ & 118.67 & 8.25 & {$[22][19][25]$} \\
\hline Extruded polystyrene & $(4.6 \mathrm{E}-07)-(5.9 \mathrm{E}-07)$ & 156-180 & 127.31 & 13.22 & {$[22][19][25]$} \\
\hline Phenol formaldehyde & $(4.2 \mathrm{E}-07)-(1.1 \mathrm{E}-07)$ & 302.63 & 52 & 3.508 & {$[22][28]$} \\
\hline Polyurethane & $(1 \mathrm{E}-07)-(5.6 \mathrm{E}-07)$ & 303.78 & 99.63 & 6.51 & {$[22][25][28]$} \\
\hline Polyisocyanurate & $(4.6 \mathrm{E}-07)-(5.4 \mathrm{E}-07)$ & $250.12-286.59$ & 65.08 & 3 & {$[22][19]$} \\
\hline \multicolumn{6}{|c|}{ Renewable } \\
\hline Cellulose (paper wool) & $(4.2 \mathrm{E}-07)-(2.6 \mathrm{E}-07)$ & 175.71 & 19.39 & 0.73 & {$[22][19]$} \\
\hline Coconut & (1.7E-07)-(1.9E-07) & 482 & & & {$[22]$} \\
\hline Flax (flax wool) & $(1.1 \mathrm{E}-06)-(2.5 \mathrm{E}-07)$ & 116.77 & 49 & 2.36 & {$[22][19]$} \\
\hline Hemp (hemp wool) & $(7.5 \mathrm{E}-07)-(2.9 \mathrm{E}-07)$ & 108.07-138.93 & 35.55 & 0.26 & {$[22][19]$} \\
\hline Recycled cotton & $(9.8 \mathrm{E}-07)-(6.1 \mathrm{E}-07)$ & 138 & & & {$[22][19]$} \\
\hline Sheep wool & $(2.1 \mathrm{E}-06)-(9.4 \mathrm{E}-07)$ & 200 & 17.12 & 1.46 & {$[22][19][25]$} \\
\hline Wood wool & $(3.3 \mathrm{E}-07)-(2 \mathrm{E}-07)$ & $190-236.44$ & 255.36 & 1.56 & {$[22][19][25]$} \\
\hline Expanded cork & $(2 \mathrm{E}-07)-(1.5 \mathrm{E}-07)$ & $155.98-319.14$ & 378.65 & 5.93 & {$[22][19][25]$} \\
\hline
\end{tabular}


The functional unit (f.u.) is defined as the mass (kg) of insulation material that involves a thermal resistance $\mathrm{R}$-value of $1\left(\mathrm{~m}^{2} \mathrm{~K} / \mathrm{W}\right)$ and an area $\mathrm{A}$ of $1 \mathrm{~m}^{2}$ for a service life period of 50 years [13]:

$$
f . u=R \lambda \rho A
$$

The aim of this study is to trace path for future construction materials in terms of energy conservation through building energy demand reduction. Research in this area mainly focuses on natural storage with phase change materials and the use of natural insulating materials.

\section{MATERIALS AND METHOD}

Reducing building energy demand in the future will be more based on the natural insulation materials and phase change material (PCMs). Today's researchers mainly focus on the application of PCMs in the building envelope for passive design [29] and the use of natural and renewable materials for thermal insulation [30]. The material can be examined in seven different categories such as: PCMs, vacuum insulation materials, aerogel, nano insulation materials, gas insulation materials, nanocon and dynamic insulation materials. Information on these categories and insulation materials can be seen in Table IV

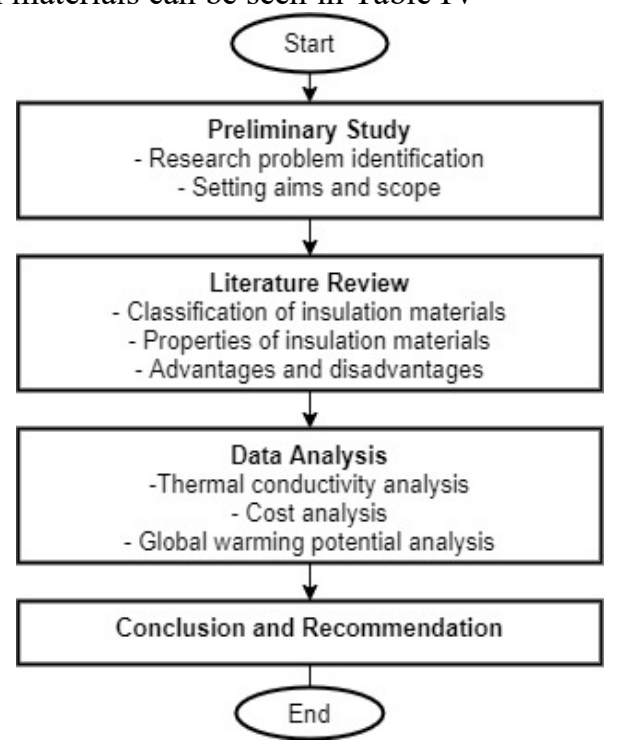

Fig. 2 Flow chart of the research stages.

TABLE IV

FUTURE OF BUILDING THERMAL INSULATIONS

\begin{tabular}{|c|c|c|c|c|c|c|}
\hline Materials & Characteristic & Structure filled & $\begin{array}{c}\text { Thermal } \\
\text { Conductivity }\end{array}$ & Advantages & Disadvantages & Ref. \\
\hline $\begin{array}{l}\text { Phase } \\
\text { Change } \\
\text { Materials } \\
\text { (PCM) }\end{array}$ & $\begin{array}{l}\text { - Suitable melting } \\
\text { temperature, } \\
\text { - Low volume changes } \\
\text { due to the phase change, } \\
\text { - No corrosive for } \\
\text { organic, } \\
\text { - No flammable for } \\
\text { inorganic }\end{array}$ & $\begin{array}{l}\text { - Solid before melting. } \\
\text { - Liquid after melting. }\end{array}$ & $\begin{array}{l}\text { Around } 0.2- \\
0.5 \mathrm{~W} / \mathrm{mK}\end{array}$ & $\begin{array}{l}\text { - High enthalpy, } \\
\text { - Large temperature ranges, } \\
\text { - Negligible volume } \\
\text { change, } \\
\text { - Chemical stability and } \\
\text { recyclable }\end{array}$ & $\begin{array}{l}\text { - Sub-cooling and } \\
\text { corrosion for } \\
\text { inorganic PCM, } \\
\text { - Flammability and } \\
\text { larger volume } \\
\text { change for organic } \\
\text { PCM; } \\
\text { - Limited thermal } \\
\text { cycling, }\end{array}$ & $\begin{array}{l}{[44]} \\
{[36]} \\
{[45]} \\
{[17]} \\
{[46]} \\
{[42]}\end{array}$ \\
\hline Aerogel & $\begin{array}{l}\text { - Melting temperature up } \\
\text { to } 950^{\circ} \mathrm{C}\end{array}$ & $\begin{array}{l}\text { - About } 99.8 \% \text { of aerogel } \\
\text { is air. } \\
\text { - The rest can be formed } \\
\text { out of organic polymers, } \\
\text { carbon, , copper, gold and } \\
\text { iron oxide. }\end{array}$ & $\begin{array}{l}\text { Very low } \\
0.005-0.1 \\
\mathrm{~W} / \mathrm{mK}\end{array}$ & $\begin{array}{l}\text { - Very low thermal } \\
\text { conductivity and specific } \\
\text { surface area, } \\
\text { - Good sound insulator, }\end{array}$ & $\begin{array}{l}\text { - Very brittle and } \\
\text { easy to break }\end{array}$ & $\begin{array}{l}{[45]} \\
{[47]} \\
{[48]} \\
{[49]} \\
{[50]}\end{array}$ \\
\hline $\begin{array}{l}\text { Vacuum } \\
\text { insulation } \\
\text { (VIP) }\end{array}$ & $\begin{array}{l}\text { - Contains a small pore } \\
\text { structure } \\
\text { - Homogeneous }\end{array}$ & - Vacuum & $\begin{array}{l}\text { less than } \\
0.04 \mathrm{mK}\end{array}$ & $\begin{array}{l}\text { - Can be tailored and } \\
\text { mounted from any place } \\
\text { without any deterioration in } \\
\text { thermal conductivity., } \\
\text { - Service life for over } 100 \\
\text { years. }\end{array}$ & $\begin{array}{l}\text { - Possible } \\
\text { penetration of air } \\
\text { and moisture to the } \\
\text { pores. }\end{array}$ & $\begin{array}{l}{[45]} \\
{[51]} \\
{[52]}\end{array}$ \\
\hline $\begin{array}{c}\text { Gas } \\
\text { insulation }\end{array}$ & $\begin{array}{l}\text { - Contains a small pore } \\
\text { structure } \\
\text { - Homogeneous }\end{array}$ & - Argon, xenon, krypton & $\begin{array}{l}\text { less than } \\
0.004 \mathrm{~W} / \mathrm{mK}\end{array}$ & $\begin{array}{l}\text { - Can be tailored and } \\
\text { installed at desired place, } \\
\text { without degradation of } \\
\text { thermal conductivity, }\end{array}$ & $\begin{array}{l}\text { - Possible } \\
\text { penetration of air } \\
\text { and moisture to the } \\
\text { pores. }\end{array}$ & [50] \\
\hline $\begin{array}{c}\text { Nano } \\
\text { insulation }\end{array}$ & $\begin{array}{l}\text { - Contains a small } \\
\text { open/closed pore structure } \\
\text { - Homogeneous }\end{array}$ & $\begin{array}{l}\text { - The pore size is less } 40 \\
\mathrm{~nm}\end{array}$ & $\begin{array}{l}\text { less than } \\
0.004 \mathrm{~W} / \mathrm{mK}\end{array}$ & $\begin{array}{l}\text { - Low thermal conductivity } \\
\text { is achieved using the } \\
\text { Knudsen effect. }\end{array}$ & $\begin{array}{l}\text { - Increased thermal } \\
\text { radiation at certain } \\
\text { wavelengths. }\end{array}$ & $\begin{array}{l}{[53]} \\
{[54]} \\
{[53]}\end{array}$ \\
\hline $\begin{array}{l}\text { Dynamic } \\
\text { insulation }\end{array}$ & $\begin{array}{l}\text { - Phonon-based thermal } \\
\text { conductivity. }\end{array}$ & & $\begin{array}{l}- \text { Can be } \\
\text { dynamically } \\
\text { adjusted from } \\
\text { very low to } \\
\text { very high. }\end{array}$ & $\begin{array}{l}\text { - Possibility to control } \\
\text { thermal conductivity within } \\
\text { a desirable range. }\end{array}$ & & $\begin{array}{l}{[55]} \\
{[56]}\end{array}$ \\
\hline NanoCon & $\begin{array}{l}\text { - Contains a small } \\
\text { open/closed pore structure } \\
\text { - Homogeneous }\end{array}$ & $\begin{array}{l}\text { With material properties } \\
\text { that are equal or greater } \\
\text { than those of concrete. }\end{array}$ & $\begin{array}{l}\text { less than } \\
0.004 \mathrm{~W} / \mathrm{mK}\end{array}$ & $\begin{array}{l}\text { - They have a huge } \\
\text { potential of joining to nano } \\
\text { insulation materials. }\end{array}$ & & $\begin{array}{l}{[54]} \\
{[53]}\end{array}$ \\
\hline
\end{tabular}


PCMs applications in the building envelope are a promising way to reduce building energy demand. These materials are used to store energy as secret storage at a temperature range that can be used at night or at the highest energy demand. The use of PCMs in the building envelope and component helps to reduce the internal temperature difference as part of the building structure or as part of a heat exchanger of a building heating system [31], [32], [33]. The phase transition temperature must be close to the comfort temperature. Therefore, materials with gas transition temperatures between 20 and 32 are ideal for passive concepts. To increase thermal mass of buildings, PCM were are applied within building structure such as concrete [34], [35], bricks [36], [37], wallboards [38], [39], [40], mortar [41], building components [42], [43] or as part of active heating/cooling system [31]. The open porous structure panel of fumed silicate, a byproduct of VIP production, high purity silicon production, forms the panel. The fumed silica is compacted until it reaches $200 \mathrm{~kg} / \mathrm{m}^{3}$ of condensation [32], [57]. This compression creates a feature well below the free path of atmospheric gas molecules at pressure ratings below 1 bar [58], [59]. The formed panels are wrapped with metallic polymer layers. Since the general structure is porous, vacuum can be applied. After this process, the edges of the polymer layers are heat sealed to protect the vacuum [60]. Other materials can also be used for porous core structure. However, fumed silica is widely used for building insulation [22]. Aging with it, however, has a negative effect on panels. Panels are not completely airtight. Therefore, the panel's thermal conductivity depends on the type of envelope used [25]. The most important material used in aerogel production is silicone. Aerogel production can divide aerogel production into two parts: making gel and drying gel. The first step to make aerogel production is to make a gel. It is then obtained by adding silicon alkoxide and water to an ethanol solution. The gel is formed when water reacts with alkoxide, and $\mathrm{SiO}_{2}$ is formed. In an overly critical drying process, the $\mathrm{SiO}_{2}$ structure is retained intact by the separation of liquids. This structure is filled with gas. After supercritical drying, aerogel can be used for insulation [61], [62], [63]. Aerogels are glued to the surface to insulate [64]. For this, aerogel granules are blown into the cavity. Their acoustical properties are very good. 7 $\mathrm{mm}$ thickness leads to a sound reduction of $60 \mathrm{~dB}$ [22]. The production cost of aerogel is very high. The aerogel has high compression strength. However, very low tensile strength causes breakage. The tensile strength can be increased by adding the carbon fiber matrix [65]. Gas-filled panels (GFP) are an advanced application of thermal insulation to maintain ambient temperature. GFPs consist of multilayer compartments wrapped with an infrared reflective house enclosed barrier and filled with air with a low conductivity value at atmospheric pressure [66]. GFPs can be used in the construction site without heat loss with low thermal conductivity. While the barrier is hermetically sealed to protect the gas filling, baffles are necessary to suppress convection and radiation. However, it has been found that the thermal conductivity of GFPs used as prototypes is a little higher than conventional insulation. Therefore, the use of GFPs in the field of insulation is still controversial. Nano insulation materials are used in VIP and GFPs. In order to prevent deterioration of the VIP and GFP grid structure, air and moisture penetration into the pore structures must be prevented [52]. Materials used when placing VIPs and GFPs on the wall cause thermal bridges. Ideally, this disadvantage is eliminated if $100 \%$ airtight and waterproof VIP and GFP structures can be made [67]. Nano insulation materials are used to obtain this structure [67], [68]. Generally, thermal insulation materials are considered to be static, that is, insulation materials have an unchangeable constant value. The choice of normal thermal insulation is made as physically as low as possible in terms of thermal conductivity and economic and construction constraints. However, heat properties are chosen according to the demands of energy and user comfort. This can be solved by the dynamic thermal insulation material (DIM), in which the thermal conductivity can be resolved within a desired range. DIMs can form part of an insulating coating of a smart building that provides storage of accumulated solar energy day and night and dynamic control of solar energy with the help of glass systems [69].

\section{A. Application of Materials}

It is common to insulate the building where heat transfer is intensive, including windows, doors, and walls. Thermal insulation significantly helps maintain energy efficiency depending on air temperature, geographical location, climate conditions, and type of heating area. Most of the work is concerned with applying insulation material in conventional building construction [70]. This section describes thermal insulation materials' applications in walls, roof, windows, floor, and ceilings but only for the conventional construction of buildings. Insulation on walls Wood and brick walls have less thermal conductivity than metal and glass. Since the walls cover a large part of a building, thermal insulation directly affects the total heat gain [36]. The insulation materials are placed seriously affect the heat flow performance of the insulation materials on the outer wall of a building. To get the best performance from the insulation material, it must be mounted in the area where the heat inlet and outlet are located. However, the insulating materials are mounted in or between the wall cavities [71].

1) Insulation on Roof and Ceiling: Direct sunlight all day long causes the roof to receive significant amount of radiation heat. Roofs make up $32 \%$ of the residential areas and can provide large amounts of heat gain in buildings. In regions with a cold climate, the insulation process is limited only by the ceiling. Snow melting patterns on the roofs are the most important indicator of energy efficiency in buildings. This is an indication of wasted heat loss in the attic [46].

2) Insulation on Windows: Windows are the secondlargest source of heat in a very well insulated house. The nature of the window is usually transparent. It is directly affected by the surrounding airflow and solar radiation because the light can pass through the conditioned area and carry heat. Heat loss/recovery of windows, collective insulation, and minimization of glass can be controlled. Two of the most common methods used in windows are gas-filled and low emission coating [72]. Low emission coatings are metal and metal oxide layers that accumulate on the surface of the window glass. These are used to suppress the flow of radiation through reflection. Meanwhile, the gas filler, which has a lower thermal conductivity, fills the window panels' 
gaps. Argon is commonly used as a gas in gas-filled insulated glasses.

3) Insulation on Floor: It is recommended to insulate floors such as unheated areas and concrete slabs properly. The insulation process is adapted around the base plates. However, it is assumed that the basement floors' insulation of reinforced concrete floors has a limited value. Because heat transfer to the floor in basements is relatively low. This is due to minor temperature changes between the section under the floor and the air above the floor [73]. Table V shows the work done by several researchers and the thermal insulation in some parts of the building. The insulation of the buildings is done by using various thermal insulation materials. During this process, the thermal conductivity values of the materials play a big role.

TABLE V

RECENT STUDIES RELATED TO THE APPLICATION OF BUILDING INSULATION

\begin{tabular}{|c|c|c|c|}
\hline Building component & Material & Thermal Conductivity (W/mK) & References \\
\hline \multirow[t]{11}{*}{ Floor } & Fiberglass & $0.04-0.033$ & {$[26][45][75]$} \\
\hline & Rockwool & 0.037 & {$[26][45][75]$} \\
\hline & Polyethylene & 0.041 & {$[26][45][75]$} \\
\hline & Cellulose & $0.054-0.046$ & {$[26][45][74]$} \\
\hline & Perlite & $0.06-0.04$ & {$[26][45][74]$} \\
\hline & Vermiculite & $0.068-0.063$ & {$[26][45][74]$} \\
\hline & Expanded Polystyrene & $0.038-0.037$ & {$[26][45][75]$} \\
\hline & Extruded Polystyrene & $0.032-0.030$ & {$[26][45][75]$} \\
\hline & VIP & $0.0343-0.0760$ & {$[76][77][78]$} \\
\hline & Aerogel & $0.0687-0.1151$ & {$[79][80]$} \\
\hline & PCM & $0.021-0.05$ & {$[71][36][43]$} \\
\hline \multirow[t]{10}{*}{ Wall } & Fiberglass & $0.04-0.033$ & {$[80]$} \\
\hline & Rockwool & 0.037 & {$[26][45][74]$} \\
\hline & Polyethylene & 0.041 & {$[26][45][75][82]$} \\
\hline & Expanded Polystyrene & $0.038-0.037$ & {$[26][45][82]$} \\
\hline & Extruded Polystyrene & $0.032-0.030$ & {$[26][45][82]$} \\
\hline & Aerogel & $0.01-0.04$ & {$[83][84][85]$} \\
\hline & PCM & $0.021-0.05$ & {$[71][36][43]$} \\
\hline & Gas-filled panel & $0.0106-0.0350$ & {$[51]$} \\
\hline & VIP & $0.0343-0.0760$ & {$[75][76][77]$} \\
\hline & Cellulose & $0.054-0.046$ & {$[45][75]$} \\
\hline \multirow[t]{2}{*}{ Window } & Aerogel & $0.017-0.023$ & {$[83][84][85]$} \\
\hline & PCM & $0.021-0.05$ & {$[86][88][89]$} \\
\hline \multirow[t]{4}{*}{ Ceiling } & Rockwool & 0.040 & {$[45][75]$} \\
\hline & Cellulose & $0.054-0.046$ & {$[45][75]$} \\
\hline & Perlite & $0.06-0.04$ & {$[45][75]$} \\
\hline & Vermiculite & $0.068-0.063$ & {$[45][75]$} \\
\hline \multirow[t]{9}{*}{ Roof } & Fiberglass & $0.04-0.033$ & {$[45][75]$} \\
\hline & PCM & $0.021-0.05$ & {$[87][88][89]$} \\
\hline & Rockwool & 0.037 & {$[45][75]$} \\
\hline & Polyethylene & 0.041 & {$[45][75]$} \\
\hline & Expanded Polystyrene & $0.038-0.037$ & {$[45][75]$} \\
\hline & Extruded Polystyrene & $0.032-0.030$ & {$[45][75]$} \\
\hline & Gas-filled panel & $0.0106-0.0350$ & {$[51]$} \\
\hline & VIP & $0.0343-0.0760$ & {$[51][90]$} \\
\hline & Cellulose & $0.054-0.046$ & {$[45][75]$} \\
\hline
\end{tabular}

\section{RESULTS AND DISCUSSION}

The choice of materials in thermal insulation has a significant effect on the energy efficiency of the building. Accurate insulation increases the energy efficiency of the building. It is doubtful whether the traditional materials commonly used in the market are the right thermal insulation material because many renewable insulation materials will be an alternative to them. 


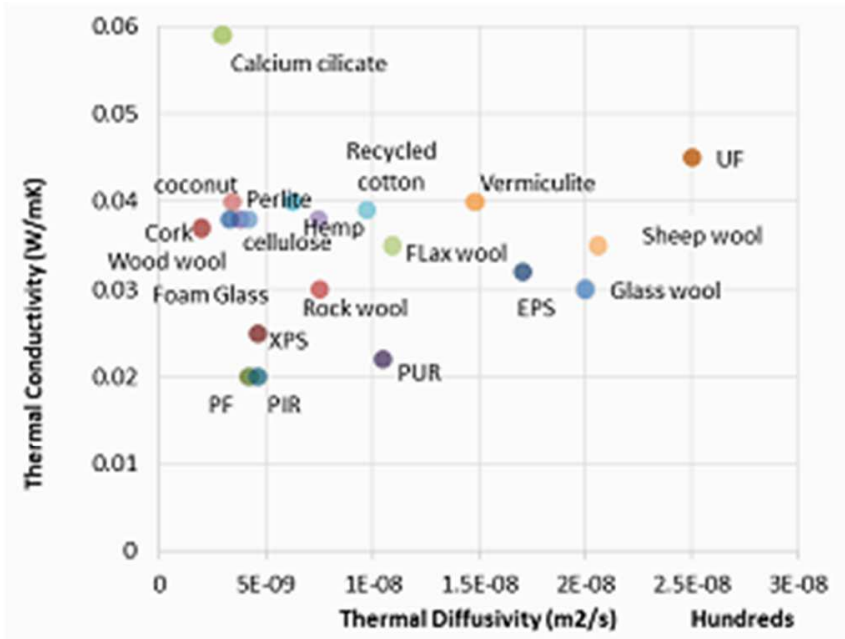

$\begin{array}{llll}\text { - glass wool } & \text { - rock wool } & \text { - calcium cilicate - foam glass } \\ \text { - perlite } & \text { - vermiculite } & \text { - EPS } & \text { - XPS } \\ \text { - PF } & \text { - PUR } & \text { - PIR } & \text { - UF } \\ \text { - cellulose } & \text { - coconut } & \text { - flax wool } & \text { - hemp } \\ \text { - recycled cotton } & \text { - sheep wool } & \text { - wood wool } & \text { - cork }\end{array}$

Fig. 3 Evaluation of thermal conductivity-thermal diffusivity of insulation materials

It is clearly shown in Figure 3 that renewable insulation materials may be an alternative to conventional insulation materials. Widely used items in the market have good properties such as stone wool, glass wool, EPS, XPS performance. However, when it is looked at Figure 3, there are renewable insulation materials that can compete with these materials. Especially, sheep's wool is in the same region as glass wool. Moreover, the presence of flax in the same region as the stone wool proves that these materials are a good thermal insulation material when they are not underestimated.

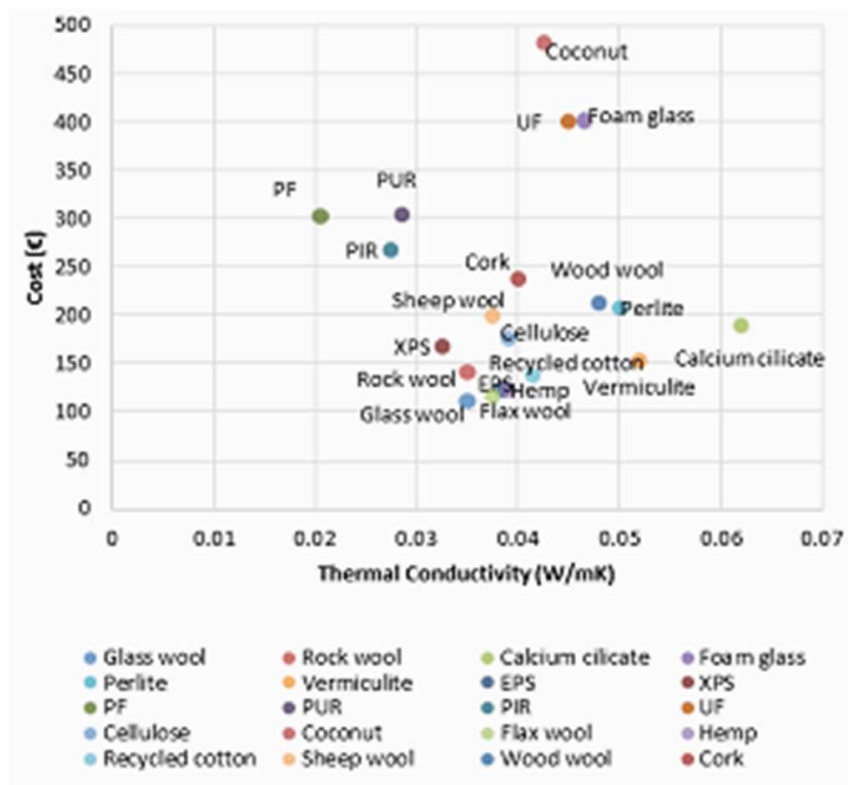

Fig. 4 Evaluation of cost-thermal conductivity of insulation materials

One of the critical points in the selection of insulation material is the price. Once again, renewable insulation materials can compete with traditional insulation materials at significant levels. This is clearly seen in Figure 4. If the price and thermal conductivity are considered, the renewable insulation materials are almost in the same region. If it is not compared with the traditional insulation materials that are widely used, there is the same region of stone wool and glass wool with renewable insulation materials such as sheep wool, recycled wool, hemp, and cork. This explains that renewable insulation materials are not significantly different in price from stone wool and glass wool, which have a large market share. Many renewable insulation materials that do not have a drawback in terms of the price should be used comfortably.

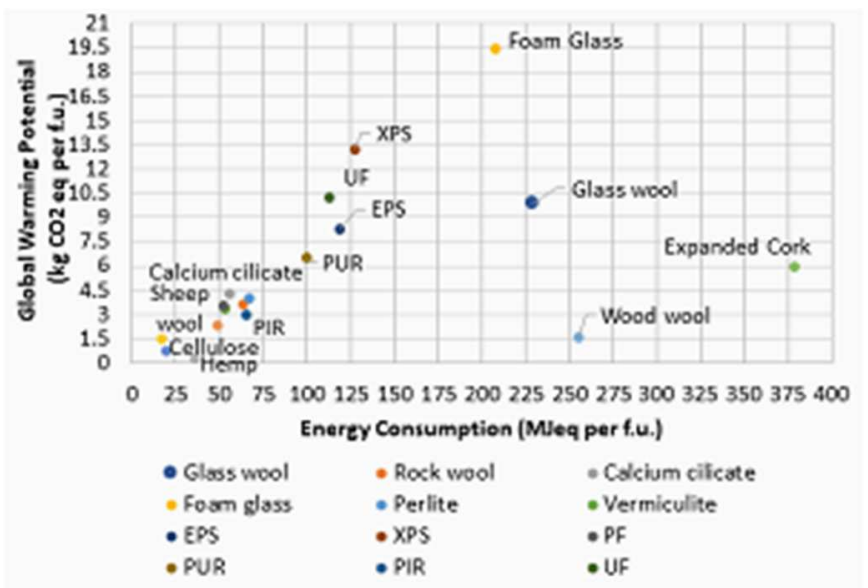

Fig. 5 Evaluation of energy consumption-global warming potential of insulation materials

Among the essential performances affecting material selection, the other two are energy consumption and global warming potential. Today, many global warming studies are being carried out studies on environmentally friendly and sustainable insulation [91]. Energy consumption is also a separate factor. Excessive operations applied while producing insulation material increase the cost as well as of residential construction project duration [92]. Therefore, the price of the material is increasing in the market. When it is carefully examined in Figure 5, it can be seen that the renewable insulation materials are considerably different from conventional insulation materials. Renewable insulation materials are the best environmentally friendly insulation materials. Even the best environmentally friendly conventional insulation material does not approach the low value of renewable insulation materials.

\section{CONCLUSION}

Based on these findings, natural insulation materials are recommended instead of insulation materials that cause high heat resistance, reduce energy consumption, have a low environmental impact, and have low thermal conductivity. Based on Figure 5, it is observed that natural insulation materials have a lower impact on global warming since they require lower energy consumption. From Figure 4 it is observed that natural insulation materials are much cheaper for the same thermal properties. Overall, natural insulation materials have a longer useful lifetime and competitive fire resistance. Phase change materials are auspicious as energy storage solutions for active and passive building heating and cooling concepts. Many studies have been done in this field with increasing applications in practice as well. Generally, research in this field is still immature. Therefore, this paper 
investigated overall problems and found that further research is required to get this technology applicable in full scale, which includes trainings and challenges for tomorrow's workforce.

\section{REFERENCES}

[1] "Breakdown of Electricity Generation by Energy Source | The Shift Project Data Portal." http://www.tsp-data-portal.org/Breakdown-ofElectricity-Generation-by-Energy-Source\#tspQvChart (accessed Feb. $12,2020)$.

[2] "World Coal Association. Coal Statistics." http://www.worldcoal.org/resources/coal-statistics (accessed Sep. 12, 2019).

[3] E. Moretti, E. Belloni, and F. Agosti, "Innovative mineral fiber insulation panels for buildings: Thermal and acoustic characterization," Appl. Energy, vol. 169, pp. 421-432, May 2016, doi: 10.1016/j.apenergy.2016.02.048.

[4] H. Benkreira, A. Khan, and K. V. Horoshenkov, "Sustainable acoustic and thermal insulation materials from elastomeric waste residues," Chem. Eng. Sci., vol. 66, no. 18, pp. 4157-4171, Sep. 2011, doi: 10.1016/j.ces.2011.05.047.

[5] K. G. M. Saidi Hassani Alaoui, "Numerical and Mathematical modeling of dynamic thermal behavior of building," J. Mater. Environ. Sci. , vol. 8, no. 4, pp. 1428-1433, 2017, Accessed: Feb. 12, 2020. [Online]. Available: http://www.jmaterenvironsci.com/.

[6] N. Farhat and Z. Inal, "Solar thermal energy storage solutions for building application: State of the art," Heritage and Sustainable Development, vol. 1, no. 1, pp. 1-13, Jun. 2019.

[7] E. Örnek, "Sustainable characteristics of the vernacular house and its impact to the building physics," Heritage and Sustainable Development, vol. 1, no. 1, pp. 14-20, Jun. 2019.

[8] B. Durakovic and M. Torlak, "Simulation and experimental validation of phase change material and water used as heat storage medium in window applications," J. Mater. Environ. Sci., vol. 8, no. 5, pp. 1837$1846,2017$.

[9] F. Findik and K. Ermiș, "Thermal energy storage,"Sustainable Engineering and Innovation, vol. 2, no. 2, pp. 66-88, Jul. 2020, doi: 10.37868/sei.v2i2.115.

[10] A. Ghaffarianhoseini, N. D. Dahlan, U. Berardi, A. Ghaffarianhoseini, N. Makaremi, and M. Ghaffarianhoseini, "Sustainable energy performances of green buildings: A review of current theories, implementations and challenges," Renewable and Sustainable Energy Reviews, vol. 25. Pergamon, pp. 1-17, Sep. 01, 2013, doi: 10.1016/j.rser.2013.01.010.

[11] B. Durakovic, "Design of Experiments Application, Concepts, Examples: State of the Art," Period. Eng. Nat. Sci., 2018.

[12] F. Asdrubali, A. L. Pisello, F. D'Alessandro, F. Bianchi, M. Cornicchia, and C. Fabiani, "Innovative cardboard based panels with recycled materials from the packaging industry: Thermal and acoustic performance analysis," in Energy Procedia, Nov. 2015, vol. 78, pp. 321-326, doi: 10.1016/j.egypro.2015.11.652.

[13] F. Ardente, M. Beccali, M. Cellura, and M. Mistretta, "Building energy performance: A LCA case study of kenaf-fibres insulation board," Energy Build., vol. 40, no. 1, pp. 1-10, Jan. 2008, doi: 10.1016/j.enbuild.2006.12.009.

[14] M. Halilovic and M. Alibegovic, "Potential of air quality improvements in Sarajevo using innovative architecture approach," Period. Eng. Nat. Sci., vol. 5, no. 2, pp. 128-135, Mar. 2017, doi: 10.21533/pen.v5i2.89

[15] A. Krdžalić and L. Hodžić, "Sustainable engineering challenges towards Industry 4.0: A comprehensive review," Sustainable Engineering and Innovation, vol. 1, no. 1, pp. 1-23, Jun. 2019.

[16] S. H. Hussein, Z. R. Abdulla, and N. M. Daood, "Urban regeneration through post-war reconstruction: Reclaiming the urban identity of the old city of Mosul," Period. Eng. Nat. Sci., vol. 7, no. 1, pp. 294-301, Apr. 2019, doi: 10.21533/pen.v7i1.331.

[17] N. Pargana, M. D. Pinheiro, J. D. Silvestre, and J. De Brito, "Comparative environmental life cycle assessment of thermal insulation materials of buildings," Energy Build., vol. 82, pp. 466-481, Aug. 2014, doi: 10.1016/j.enbuild.2014.05.057.

[18] M. Volf, J. Diviš, and F. Havlík, "Thermal, moisture and biological behaviour of natural insulating materials," in Energy Procedia, Nov. 2015, vol. 78, pp. 1599-1604, doi: 10.1016/j.egypro.2015.11.219.

[19] S. Mounir, A. Khabbazi, A. Khaldoun, Y. Maaloufa, and Y. El Hamdouni, "Thermal inertia and thermal properties of the composite material clay-wool," Sustain. Cities Soc., vol. 19, pp. 191-199, Dec. 2015, doi: 10.1016/j.scs.2015.07.018.

[20] X. G. Casals, "Analysis of building energy regulation and certification in Europe: Their role, limitations and differences," Energy Build., vol 38, no. 5, pp. 381-392, May 2006, doi: 10.1016/j.enbuild.2005.05.004.

[21] P. Najifar and C. Kurtay, "Harvesting feasibility of rain water in buildings," Period. Eng. Nat. Sci., vol. 6, no. 1, pp. 144-152, Sep. 2018, doi: 10.21533/pen.v6i1.197.

[22] S. Schiavoni, F. D'Alessandro, F. Bianchi, and F. Asdrubali, "Insulation materials for the building sector: A review and comparative analysis," Renewable and Sustainable Energy Reviews, vol. 62. Elsevier Ltd, pp. 988-1011, Sep. 01, 2016, doi: 10.1016/j.rser.2016.05.045.

[23] S. Lehner, "European fire classification of construction products, new test method 'SBI', and introduction of the European classification system into German building regulations," Otto-Graf-Journal, vol. 16, 2005.

[24] S. Kowatsch, "Mineral wool insulation binders," in Phenolic Resins: A Century of Progress, Springer Berlin Heidelberg, 2010, pp. 209-242.

[25] M. J. Duijve, "Comparative assessment of insulating materials on technical,environmental and health aspects for application in buildingrenovation to the Passive house level," Dec. 2012.

[26] B. P. Jelle, "Traditional, state-of-the-art and future thermal building insulation materials and solutions - Properties, requirements and possibilities," Energy and Buildings, vol. 43, no. 10. Elsevier Ltd, pp. 2549-2563, Oct. 01, 2011, doi: 10.1016/j.enbuild.2011.05.015.

[27] D. A. L. Silva, F. A. R. Lahr, L. D. Varanda, A. L. Christoforo, and A. R. Ometto, "Environmental performance assessment of the melamineurea-formaldehyde (MUF) resin manufacture: A case study in Brazil," J. Clean. Prod., vol. 96, pp. 299-307, Jun. 2015, doi: 10.1016/j.jclepro.2014.03.007.

[28] B. Berge, The ecology of building materials. Elsevier/Architectural Press, 2009.

[29] B. Duraković, "Conclusion," in PCM-Based Building Envelope Systems, Springer Nature, 2020, pp. 183-190.

[30] M. Durakovic, B, Yıldı, G, Yahia, "Comparative performance evaluation of conventional and renewable thermal insulation materials used in building envelops," Teh. Vjesn. - Tech. Gaz., vol. 27, no. 1, pp. 283-289, Feb. 2020

[31] B. Duraković, "PCMs in Separate Heat Storage Modules," in PCMBased Building Envelope Systems: Innovative Energy Solutions for Passive Design., Springer Nature, 2020, pp. 121-146.

[32] R. Baetens et al., "Vacuum insulation panels for building applications: A review and beyond," Energy and Buildings, vol. 42, no. 2. Elsevier, pp. 147-172, Feb. 01, 2010, doi: 10.1016/j.enbuild.2009.09.005.

[33] P. Karami, N. Al-Ayish, and K. Gudmundsson, "A comparative study of the environmental impact of Swedish residential buildings with vacuum insulation panels," Energy Build., vol. 109, pp. 183-194, Dec. 2015, doi: 10.1016/j.enbuild.2015.10.031.

[34] M. Faraji, "Numerical study of the thermal behavior of a novel Composite PCM/concrete wall," in Energy Procedia, Dec. 2017, vol. 139, pp. 105-110, doi: 10.1016/j.egypro.2017.11.181.

[35] A. Figueiredo, J. Lapa, R. Vicente, and C. Cardoso, "Mechanical and thermal characterization of concrete with incorporation of microencapsulated PCM for applications in thermally activated slabs," Constr. Build. Mater., vol. 112, pp. 639-647, Jun. 2016, doi: 10.1016/j.conbuildmat.2016.02.225

[36] B. Duraković, "PCMs in Building Structure," in PCM-Based Building Envelope Systems: Innovative Energy Solutions for Passive Design, Springer Nature, 2020, pp. 63-87.

[37] C. Hasse, M. Grenet, A. Bontemps, R. Dendievel, and H. Sallée, "Realization, test and modelling of honeycomb wallboards containing a Phase Change Material," Energy Build., vol. 43, no. 1, pp. 232-238, Jan. 2011, doi: 10.1016/j.enbuild.2010.09.017.

[38] B. Chhugani, F. Klinker, H. Weinlaeder, and M. Reim, "Energetic performance of two different PCM wallboards and their regeneration behavior in office rooms," in Energy Procedia, Sep. 2017, vol. 122, pp. 625-630, doi: 10.1016/j.egypro.2017.07.360.

[39] F. Kuznik, J. Virgone, and J. J. Roux, "Energetic efficiency of room wall containing PCM wallboard: A full-scale experimental investigation," Energy Build., vol. 40, no. 2, pp. 148-156, Jan. 2008, doi: 10.1016/j.enbuild.2007.01.022.

[40] P. Thantong and P. Chantawong, "Experimental study of a solar wall collector with PCM towards the natural ventilation of model house," in Energy Procedia, Oct. 2017, vol. 138, pp. 32-37, doi: 10.1016/j.egypro.2017.10.041 
[41] A. Karaipekli and A. Sari, "Development and thermal performance of pumice/organic PCM/gypsum composite plasters for thermal energy storage in buildings," Sol. Energy Mater. Sol. Cells, vol. 149, pp. 1928, May 2016, doi: 10.1016/j.solmat.2015.12.034.

[42] B. Duraković, "PCM-Based Glazing Systems and Components," in PCM-Based Building Envelope Systems: Innovative Energy Solutions for Passive Design., Springer Nature, 2020, pp. 89-119.

[43] M. T. Benjamin Durakovic, "Experimental and numerical study of a PCM window model as a thermal energy storage unit," Int. J. LowCarbon Technol., 2019, doi: 10.1093/ijlct/ctw024.

[44] P. Ricciardi, E. Belloni, and F. Cotana, "Innovative panels with recycled materials: Thermal and acoustic performance and Life Cycle Assessment," Appl. Energy, vol. 134, pp. 150-162, Dec. 2014, doi: 10.1016/j.apenergy.2014.07.112.

[45] X. Su, Z. Luo, Y. Li, and C. Huang, "Life cycle inventory comparison of different building insulation materials and uncertainty analysis," $J$. Clean. Prod., vol. 112, pp. 275-281, Jan. 2016, doi: 10.1016/j.jclepro.2015.08.113.

[46] B. Duraković and S. Mešetović, "Thermal performances of glazed energy storage systems with various storage materials: An experimental study," Sustain. Cities Soc., vol. 45, pp. 422-430, 2019, doi: $10.1016 /$ j.scs.2018.12.003.

[47] L. Aditya et al., "A review on insulation materials for energy conservation in buildings," Renew. Sustain. Energy Rev., vol. 73, pp. 1352-1365, Jun. 2017, doi: 10.1016/J.RSER.2017.02.034.

[48] B. Durakovic, "Application of phase change materials in glazing and shading systems: Issues, trends and developments," in 3rd International Engineering Research Symposium INERS'19, 2019, pp. 688-699, doi: http://umas.duzce.edu.tr/.

[49] N. H. N. Do et al., "Heat and sound insulation applications of pineapple aerogels from pineapple waste," Mater. Chem. Phys., vol. 242, p. 122267, Feb. 2020, doi: 10.1016/j.matchemphys.2019.122267.

[50] N. Lolli and I. Andresen, "Aerogel vs. argon insulation in windows: A greenhouse gas emissions analysis," Build. Environ., vol. 101, pp. 6476, May 2016, doi: 10.1016/j.buildenv.2016.03.001.

[51] P. K. S. Rathore and S. K. Shukla, "Potential of macroencapsulated pcm for thermal energy storage in buildings: A comprehensive review," Construction and Building Materials, vol. 225. Elsevier Ltd, pp. 723744, Nov. 20, 2019, doi: 10.1016/j.conbuildmat.2019.07.221.

[52] M. Gonçalves, N. Simões, C. Serra, and I. Flores-Colen, "A review of the challenges posed by the use of vacuum panels in external insulation finishing systems," Applied Energy, vol. 257. Elsevier Ltd, p. 114028, Jan. 01, 2020, doi: 10.1016/j.apenergy.2019.114028.

[53] H. F. Gangåssæter, B. P. Jelle, S. A. Mofid, and T. Gao, "Air-Filled Nanopore Based High-Performance Thermal Insulation Materials," in Energy Procedia, Oct. 2017, vol. 132, pp. 231-236, doi: 10.1016/j.egypro.2017.09.760.

[54] B. Petter Jelle, "Nano-based thermal insulation for energy-efficient buildings," in Start-Up Creation: The Smart Eco-Efficient Built Environment, Elsevier Inc., 2016, pp. 129-181.

[55] S. J. M. Koenders, R. C. G. M. Loonen, and J. L. M. Hensen, "Investigating the potential of a closed-loop dynamic insulation system for opaque building elements," Energy Build., vol. 173, pp. 409-427, Aug. 2018, doi: 10.1016/j.enbuild.2018.05.051.

[56] S. Rupp and M. Krarti, "Analysis of multi-step control strategies for dynamic insulation systems," Energy Build., vol. 204, p. 109459, Dec. 2019, doi: 10.1016/j.enbuild.2019.109459.

[57] E. Kucukpinar et al., "Development of transparent and opaque vacuum insulation panels for energy efficient buildings," in Energy Procedia, Nov. 2015, vol. 78, pp. 412-417, doi: 10.1016/j.egypro.2015.11.685.

[58] F. Isaia, S. Fantucci, A. Capozzoli, and M. Perino, "Vacuum insulation panels: Thermal bridging effects and energy performance in real building applications," in Energy Procedia, Dec. 2015, vol. 83, pp. 269-278, doi: 10.1016/j.egypro.2015.12.181.

[59] F. E. Boafo, Z. Chen, C. Li, B. Li, and T. Xu, "Structure of vacuum insulation panel in building system," Energy Build., vol. 85, pp. 644653, Dec. 2014, doi: 10.1016/j.enbuild.2014.06.055.

[60] Z. Chen et al., "Preparation and characterization of vacuum insulation panels with super-stratified glass fiber core material," Energy, vol. 93, pp. 945-954, Dec. 2015, doi: 10.1016/j.energy.2015.08.105.

[61] X. Zhang, X. Zhao, T. Xue, F. Yang, W. Fan, and T. Liu, "Bidirectional anisotropic polyimide/bacterial cellulose aerogels by freeze-drying for super-thermal insulation," Chem. Eng. J., vol. 385, p. 123963, Apr. 2020, doi: 10.1016/j.cej.2019.123963.

[62] E. Cuce, P. M. Cuce, C. J. Wood, and S. B. Riffat, "Optimizing insulation thickness and analysing environmental impacts of aerogel- based thermal superinsulation in buildings," Energy Build., vol. 77, pp. 28-39, Jul. 2014, doi: 10.1016/j.enbuild.2014.03.034.

[63] G. Masera et al., "Development of a Super-insulating, Aerogel-based Textile Wallpaper for the Indoor Energy Retrofit of Existing Residential Buildings,” in Procedia Engineering, Jan. 2017, vol. 180, pp. 1139-1149, doi: 10.1016/j.proeng.2017.04.274.

[64] Y. L. He and T. Xie, "Advances of thermal conductivity models of nanoscale silica aerogel insulation material," Applied Thermal Engineering, vol. 81. Elsevier Ltd, pp. 28-50, Apr. 25, 2015, doi: 10.1016/j.applthermaleng.2015.02.013.

[65] A. Rege, L. Ratke, İ. D. Külcü, and P. Gurikov, "Stiffening of biopolymer aerogel networks upon wetting: A model-based study," $J$. Non. Cryst. Solids, vol. 531, p. 119859, Mar. 2020, doi: 10.1016/j.jnoncrysol.2019.119859.

[66] R. Baetens, B. P. Jelle, A. Gustavsen, and S. Grynning, "Gas-filled panels for building applications: A state-of-the-art review," Energy and Buildings, vol. 42, no. 11. Elsevier Ltd, pp. 1969-1975, Nov. 01, 2010, doi: 10.1016/j.enbuild.2010.06.019.

[67] H. F. Gangåssæter, B. P. Jelle, and S. A. Mofid, "Synthesis of SilicaBased Nano Insulation Materials for Potential Application in LowEnergy or Zero Emission Buildings," in Energy Procedia, Sep. 2017, vol. 122, pp. 949-954, doi: 10.1016/j.egypro.2017.07.435.

[68] L. Moga and A. Bucur, "Nano insulation materials for application in nZEB," in Procedia Manufacturing, Jan. 2018, vol. 22, pp. 309-316, doi: 10.1016/j.promfg.2018.03.047.

[69] S. M. Al-Masrani and K. M. Al-Obaidi, "Dynamic shading systems: A review of design parameters, platforms and evaluation strategies," Automation in Construction, vol. 102. Elsevier B.V., pp. 195-216, Jun. 01, 2019, doi: 10.1016/j.autcon.2019.01.014.

[70] B. Durakovic, "Design for additive manufacturing: Benefits, trends and challenges," Period. Eng. Nat. Sci., vol. 6, no. 2, pp. 179-191, 2018, doi: 10.21533/pen.v6i2.224.

[71] B. Duraković, "Passive Solar Heating/Cooling Strategies," in PCMBased Building Envelope Systems: Innovative Energy Solutions for Passive Design, Springer Nature, 2020, pp. 39-62.

[72] M. S. Al-Homoud, "Performance characteristics and practical applications of common building thermal insulation materials," Build. Environ., vol. 40, no. 3, pp. 353-366, Mar. 2005, doi: 10.1016/j.buildenv.2004.05.013.

[73] G. Kirankumar, S. Saboor, S. S. Vali, D. Mahapatra, A. B. Talanki Puttaranga Setty, and K. H. Kim, "Thermal and cost analysis of various air filled double glazed reflective windows for energy efficient buildings," J. Build. Eng., vol. 28, p. 101055, Mar. 2020, doi: 10.1016/j.jobe.2019.101055

[74] S. Lu, B. Xu, and X. Tang, "Experimental study on double pipe PCM floor heating system under different operation strategies," Renew. Energy, vol. 145, pp. 1280-1291, Jan. 2020, doi 10.1016/j.renene.2019.06.086.

[75] T. Gao, L. I. C. Sandberg, and B. P. Jelle, "Nano insulation materials: Synthesis and life cycle assessment," in Procedia CIRP, Jan. 2014, vol. 15, pp. 490-495, doi: 10.1016/j.procir.2014.06.041.

[76] S. Mao, A. Kan, Z. Huang, and W. Zhu, "Prediction of thermal performance of vacuum insulation panels (VIPs) with micro-fiber core materials," Mater. Today Commun., vol. 22, p. 100786, Mar. 2020, doi: 10.1016/j.mtcomm.2019.100786.

[77] D. Tetlow et al., "Cellulosic-crystals as a fumed-silica substitute in vacuum insulated panel technology used in building construction and retrofit applications," Energy Build., vol. 156, pp. 187-196, Dec. 2017, doi: 10.1016/j.enbuild.2017.08.058.

[78] J. Zach, J. Peterková, Z. Dufek, and T. Sekavčnik, "Development of vacuum insulating panels (VIP) with non-traditional core materials," Energy Build., vol. 199, pp. 12-19, Sep. 2019, doi: 10.1016/j.enbuild.2019.06.026.

[79] H. Choi, V. G. Parale, T. Kim, Y.-S. Choi, J. Tae, and H.-H. Park, "Structural and mechanical properties of hybrid silica aerogel formed using triethoxy(1-phenylethenyl)silane," Microporous Mesoporous Mater., p. 110092, Feb. 2020, doi: 10.1016/j.micromeso.2020.110092.

[80] A. Tabernero, L. Baldino, A. Misol, S. Cardea, and E. M. M. del Valle, "Role of rheological properties on physical chitosan aerogels obtained by supercritical drying," Carbohydr. Polym., vol. 233, p. 115850, Apr. 2020, doi: 10.1016/j.carbpol.2020.115850.

[81] M. Rafiee, F. Nitzsche, J. Laliberte, S. Hind, F. Robitaille, and M. R. Labrosse, "Thermal properties of doubly reinforced fiberglass/epoxy composites with graphene nanoplatelets, graphene oxide and reducedgraphene oxide," Compos. Part B Eng., vol. 164, pp. 1-9, May 2019, doi: 10.1016/j.compositesb.2018.11.051. 
[82] H. Akeiber et al., "A review on phase change material (PCM) for sustainable passive cooling in building envelopes," Renewable and Sustainable Energy Reviews, vol. 60. Elsevier Ltd, pp. 1470-1497, Jul. 01, 2016, doi: 10.1016/j.rser.2016.03.036.

[83] L. Boussaba, A. Foufa, S. Makhlouf, G. Lefebvre, and L. Royon, "Elaboration and properties of a composite bio-based PCM for an application in building envelopes," Constr. Build. Mater., vol. 185, pp. 156-165, Oct. 2018, doi: 10.1016/j.conbuildmat.2018.07.098.

[84] Y. Zhou and S. Zheng, "Uncertainty study on thermal and energy performances of a deterministic parameters based optimal aerogel glazing system using machine-learning method," Energy, vol. 193, p. 116718, Feb. 2020, doi: 10.1016/j.energy.2019.116718.

[85] Y. Zhou and S. Zheng, "Machine learning-based multi-objective optimisation of an aerogel glazing system using NSGA-II-study of modelling and application in the subtropical climate Hong Kong," $J$. Clean. Prod., vol. 253, p. 119964, Apr. 2020, doi: 10.1016/j.jclepro.2020.119964.

[86] Y. Zhou and S. Zheng, "Climate adaptive optimal design of an aerogel glazing system with the integration of a heuristic teaching-learningbased algorithm in machine learning-based optimization," Renew. Energy, Jan. 2020, doi: 10.1016/j.renene.2020.01.133.
[87] B. Durakovic and M. Torlak, "Experimental and numerical study of a PCM window model as a thermal energy storage unit," Int. J. LowCarbon Technol., vol. 12, no. 3, pp. 272-280, 2017.

[88] S. M. Benjamin Durakovic, "Thermal Performances of Glazed Energy Storage Systems with Various Storage Materials: An Experimental study," Sustain. Cities Soc., Feb. 2019.

[89] B. Durakovic and M. Torlak, "Simulation and experimental validation of phase change material and water used as heat storage medium in window applications," J. of Material and Environmental Science, 2017.

[90] J. H. Park, J. Jeon, J. Lee, S. Wi, B. Y. Yun, and S. Kim, “Comparative analysis of the PCM application according to the building type as retrofit system," Build. Environ., vol. 151, pp. 291-302, Mar. 2019, doi: 10.1016/j.buildenv.2019.01.048.

[91] H. S. Cinar, N. N. Parlak, and N. Yildiz Dönmez, "Climate friendly urban green areas: Roadside green spaces in Sakarya/Turkey," Period. Eng. Nat. Sci., vol. 6, no. 2, pp. 159-167, Dec. 2018, doi: 10.21533/pen.v6i2.204.

[92] E. D. A. Al-Zubaidi, A. H. Yas, and H. F. Abbas, "Guess the time of implementation of residential construction projects using neural networks ANN," Period. Eng. Nat. Sci., vol. 7, no. 3, pp. 1218-1227, Sep. 2019, doi: 10.21533/pen.v7i3.680. 